\title{
Internacionālismi, to sinonīmi un svešcilmes un pašcilmes priedēkḷi
}

\section{International verbs, their synonyms and prefixes of a native and a foreign origin}

\author{
Daiga Deksne \\ Latvijas Universitāte, Humanitāro zinātņu fakultāte \\ Latviešu un vispārīgās valodniecības katedra \\ Visvalža iela 4a, Rīga, LV-1050 \\ Tilde \\ Vienības gatve 75a, Rīga, LV-1004 \\ E-pasts: daiga.deksne@tilde.lv
}

Ievērojamu valodas leksikas daļu veido aizguvumi. Aizgūt var gan atsevišķus afiksus, gan arī ar šādiem afiksiem jau atvasinātus verbus. Pētījumā tiek aplūkoti svešcilmes verbi, kuri jau pirms aizgūšanas atvasināti ar latīṇu cilmes priedēkḷiem re-, de-, in-, ko-, ad-, ab-, a-, eks-, sub-, pre-, pro-, kā arī svešcilmes piedēkḷu izmantojums, darinot verbus latviešu valodā. Tiek aplūkota iespēja dažādas cilmes verbu saknēm pievienot dažādas cilmes priedēkḷus. Pētījuma mērkisis ir gūt ieskatu par to, kādas ir attiecības starp internacionālismiem, to pašcilmes sinonīmiem un svešcilmes un pašcilmes priedēkḷiem mūsdienu latviešu valodas leksikā.

Atslēgvārdi: verbs; priedēklis; prefiksācija; internacionālisms; sinonīmija.

\section{levads}

Latviešu literārajā valodā ir vienpadsmit pašcilmes priedēkḷlu (aiz-, ap-, $a t-, i e-, i z-, n o-, p a-, p \bar{a} r-, p i e-, s a-, u z-)$, kuri aktīvi tiek izmantoti jaunu verbu darināšanā un esošu verbu nozīmju modificēšanā, un priedēklis ne-, kurš izsaka to, ka motivētājverba izteiktā darbība netiek veikta, nav iespējama vai nav vēlama. (Soida 2009, 227-231; Vulāne 2015, 278-291). Līdztekus valodu bagātina verbi, kuru darināšanā izmantoti svešcilmes prefiksālie elementi. Latviešu valoda ir bagāta aizguvumiem, kuri valodā ienākuši dažādos laika posmos. Daudzi aizgūti vārdi tik dziḷi iesakṇojušies valodā, ka netiek vairs izjusti kā sveši, to cilme pat grūti nosakāma. Mantoti vārdi un nacionāli aizguvumi turpmāk pētijumā tiks dēvēti par pašcilmes vārdiem pretstatā internacionālajiem aizguvumiem (piem., internacionālisms repatriēties) vai aizguvumiem ar internacionālu prefiksu (piem., anglicisms retvītot) jeb svešcilmes vārdiem. Aizgūt var gan atsevišķus afiksus, piem., latīṇu cilmes prefiksus $r e-, a-, d e-$, gan arī ar šādiem afiksiem jau atvasinātus vārdus, piem., reabilitēt. Verbi, kurus ievada latīnnu cilmes prefiksāli elementi, veido nozīmīgu latviešu valodas leksikas daļu. Valentīna Skujiṇa $(2002,139)$ norāda, ka „arī mūsdienās internacionālā zinātniskā terminolog̣ija tiek veidota galvenokārt uz latīņu un grieķu elementu bāzes, turklāt izmantojot gan tieši latīņu un grieķu 
cilmes elementus, gan tādus elementus, kuru sākotne (etimons) meklējama latīṇu un grieķu valodā". Mūsdienu latviešu valodā ir aptuveni 50 internacionālas cilmes atvasinātu verbu, kuru saknē ietverts re-. Tikpat daudz ir verbu, kurus ievada invai tā alomorfs im-. Aptuveni 60 verbiem saknes sākumā ir de-. Ne tik lielā skaitā, bet tomēr diezgan bieži sastopami internacionāli aizgumumi, kurus ievada ko-, ad-, $a b-, a-, e k s-, s u b-$, pre-, pro-. Verbu skaits apzināts, izmantojot vairākus avotus, uzñēmuma Tilde morfoloğiski marķētu vārdu celmu datubāzi, latviešu valodas tekstu korpusu (pieejams www.korpuss.lv) un tekstus tīmeklī. Valodā nav daudz absolūtu sinonīmu. Parasti viens no sinonīmiem ir internacionālisms vai aizguvums no kādas citas valodas, bet otrs - pašcilmes vārds, kuru izmanto mazāk formālos valodas stilos. V. Skujiña $(2002,49)$ atzīmē, ka „no absolūtajiem sinonīmiem, t. i., vārdiem (vai vārdkopām) ar pilnīgi identu nozīmi, zinātniskā terminoloǵija cenšas atbrīvoties. Tomēr dažas sinonīmu grupas terminoloǵijā saglabājas: pašcilmes un aizgūti ekvivalenti (pareizrakstība - ortogrāfija) (..) Sinonīmija terminoloǵijas praksē liecina, ka attiecīgās nozares terminu (un parasti arī jēdzienu) sistēma vēl nav nostabilizējusies".

Pētījuma mērķis ir gūt ieskatu par to, kā mūsdienu latviešu valodas leksikā iekḷāvušies internacionālismi, to pašcilmes sinonīmi un svešcilmes un pašcilmes priedēkḷi. Pētījumā svešcilmes un pašcilmes priedēkḷu semantika tiek skaidrota, salīdzinot svešcilmes verbus ar tiem atbilstošiem pašcilmes sinonīmiem un latīnu priedēkḷu semantiku latīṇu valodā salīdzinot ar šo priedēkḷu izteiktajām nozīmēm latviešu valodā un nedaudz arī angḷu valodā.

\section{Verbu dalījums pēc priedēkḷa un saknes cilmes}

Valodā ir šādi aizgūtu vienību veidi (Kuzṇecova 2013, 117):

1) afiksi vai elementi, kurus par tādiem var uzskatīt, piem., priedēklis re-no lat. re- 'atpakal, atkal'; inter- no lat. inter- 'starp, starpā, vidū';

2) aizgūti semantiski patstāvīgi elementi, kas izmantojami jaunu vārdu darināšanā, piem., hron- no gr. chronos 'laiks';

3) vārdi, kuri aizgūti jau atvasinātā veidā, piem., demolēt.

Andra Kalnača $(2004,29)$ norāda uz morfēmu segmentācijas problēmām un atzīmē, ka ,internacionāli vārdi latviešu valodā visbiežāk tiek pārṇemti jau atvasināti ar visiem latīnsu vai grieķu cilmes prefiksiem vai postfiksiem, senāk ar vācu vai krievu valodas, mūsdienās - ar angl̦u valodas starpniecību”.

Šajā pētījumā tiek aplūkoti gan aizgūti afiksi, kuri tiek lietoti verbu darināšanā, gan jau atvasinātā veidā aizgūti verbi.

Aizgūtu afiksu izmantošana vārddarināšanā ir raksturīga daudzām valodām. Bieži vien tie ir latīn,u cilmes afiksi. Latīn,u valodā priedēkl̦u lomu visbiežāk veic prievārdi $\bar{a}, a b, a b s, a d$, ante, circum, cum, de, , $\bar{e}, e x$, in, inter, intrō, ob, per, prae, praeter, $\operatorname{prō}(d)$, qub, trāns. Kā patstāvīgi prievārdi nav sastopami priedēkḷi $a m b-$,

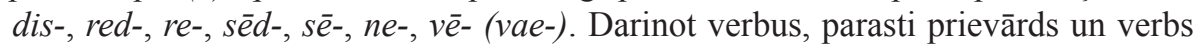
saglabā savu pamatnozīmi, tomēr atvasinājuma nozīme var būt arī atšksirīga (Allen 1903, 161-162; Strads 2014, 161-166). Angḷu valodā ir aptuveni 50 priedēkḷu, aptuveni 20 priedēkḷu tiek lietoti verbu darināšanā (Veisbergs 2001, 132, 133). Zeki Hamavands (Zeki Hamawand 2011, 55-69) atzīmē, ka angḷu valodā tiek 
lietoti gan pašcilmes priedēkḷi, gan latīṇu priedēkḷi, kuri bieži vien aizgūti ar kādu starpniekvalodu, piem., franču vai grieksu. No kognitīvās gramatikas skatupunkta priedēkḷus iedala divās grupās. Pozitīvie priedēkḷi apstiprina patiesību, pievienojot vārda nozīmei kādu niansējumu. Tiek minēti priedēkḷi ante-, be-, en $(m)$-, fore-, hyper-, inter-, intra-, macro-, maxi-, mega-, micro-, mid-, midi-, mini-, post-, pre-, super- un ultra-. Negatīvie priedēkḷi piešksir vārdam pretēju vai negatīvu nozīmi. Tiek minēti priedēkḷi $a(n)$-, ab-, anti-, contra-, counter-, de-, dis-, in-, mal-, mis-, non-, pseudo-, quasi-, semi-, sub-, un- un under-.

Aizgūtu vienību izmantošana īpaši raksturīga jaunu terminu darināšanā. V. Skujiņa lieto apzīmējumu hibrīdtermins. „Par hibrīdterminiem sauc afiksālos terminus un salikteņterminus, kas sastāv no dažādvalodu cilmes jeb - īsāk dažādcilmes elementiem. Dažādcilmes elementu apvienošana vienā vārdā ir sens, plaši izplatīts un sarežğìts, tomēr likumsakarīgs process katras kultūrtautas valodā (..) glaciologija (lat. glacies 'ledus' + gr. logos 'mācība'); intoksikācija (lat. in 'iekš' + gr. toxikon 'inde')." (Skujiņa 2002, 101) V. Skujiña atzīmē, ka valodniecībā par labākiem atzīst viencilmes darinājumus, tomēr tiek darināti arī afiksālie hibrīdtermini, kurus veido internacionāls celms un nacionāls prefiksāls elements. Tiek izmantoti pašcilmes priedēkḷi ne-, pār- vai puspriedēkḷi pēc-, škēers-, starp-, apakš-, priekšs-, pret-, virs-, caur-. V. Skujiņa $(2002,104)$ min, ka no internacionālajiem prefiksālajiem elementiem latviešu terminu darināšanā retumis tiek izmantoti priedēkḷi $a$-, de-, re-, biežāk izmanto prefiksālos elementus, kam ir puspriedēkḷa raksturs: eks-, trans-, anti-, intra-, ultra-.

Aplūkojot latviešu leksikonā paralēli lietojamus svešcilmes un pašcilmes verbus, var saskatīt piecus dažādus variantus, kā var kombinēt dažādas cilmes priedēkḷus un celmus:

1) gan svešcilmes verbam, gan tā pašcilmes sinonīmam ir pašcilmes priedēklis, piem., ieekonomēt un ietaupīt, svešcilmes verbs var būt aizgūts jau atvasinātā veidā ar ietvertu svešcilmes priedēkli, piem., pārdislocēt (svešcilmes saknē ietverts dis-) un pārvietot;

(1) Es domāju, ka vismaz 79000 latu var ieekonomēt. (SAEIMA)

(2) Šādā veidā vald̄̄ba kopā ar koalīcijas partijām cer ietaupīt 34 miljonus latu. (SAEIMA)

2) svešcilmes verbam ir gan pašcilmes, gan svešcilmes priedēklis, pašcilmes sinonīma nav, piem., atmagnetizēt un remagnetizèt vai demagnetizèt, pārfinansèt un refinansēt, pārstartēt un restartèt, svešcilmes verbs var būt aizgūts jau atvasinātā veidā ar ietvertu svešcilmes priedēkli;

(3) Restrukturējot vai kaut nedaudz privatizējot kādu no „Latvenergo” meitas uzņēmumiem, ERAB ir tiesīga jebkurā brīd̄ pieprasìt kredītlīguma saistību izpildi, un tad uz ERAB vārda pēc tās pašas izvēles var parādīties ķ̄̄la par 29 miljoniem latu, kaut vai šīs pašas nelaimīgās trīs Daugavas spēkstacijas. (SAEIMA)

(4) Ģimeņu aizsardzību var veikt, nosakot nodoklu atvieglojumus, pārstrukturējot vispārējos un mērķu pabalstus gimenēm. (SAEIMA) 
3) svešcilmes verbs aizgūts jau atvasinātā veidā, pašcilmes sinonīmam ir pašcilmes priedēklis, piem., investèt un ieguldìt, komunicèt un sazināties, reducēt un samazināt;

(5) Šeit iespējas ir skaidras, un šajā jomā strādājošo cilvēku skaits ir reducēts lìdz minimumam. (SAEIMA)

(6) Ļoti interesanti lasīt, ka mūsu valstī ir samazinājies trūcīgo skaits. (SAEIMA)

4) svešcilmes verbam ir svešcilmes priedēklis, pašcilmes sinonīmam pašcilmes priedēklis, piem., deklasificēt un atslepenot;

(7) Vai to konstatēs operatīvās izstrādes lietā, pamatojoties uz valsts slepeniem, deklasificētiem materiāliem? (SAEIMA)

(8) Pirmām kārtām jāteic, ka izteikties par to mēs varēsim tikai tad, kad būs atslepenots šis audita ziņojums vai, pareizāk sakot, konsultatīvais ziņojums, kad mēs varēsim iepazīties arī ar Augstākās izglītības padomes argumentiem par noteiktiem šajā ziņojumā ieklautajiem punktiem. (SAEIMA)

5) svešcilmes verbs aizgūts jau atvasinātā veidā, pašcilmes sinonīma nav, piem., profilèt, retvītot.

(9) Vismaz tie, kuri atbalsta eiro, retvītojiet, un tādā veidā arī tā sabiedrība, kas to veic e-vidē, uzzinās par šiem ieguvumiem un par to, kur un kas notiek. (SAEIMA)

Ar pašcilmes priedēkḷa pievienošanu svešcilmes verbam rodas iespēja izteikt darbības pabeigtību līdzīgi tam, kā tas ir pašcilmes verbiem. Pētot svešcilmes verbus ar priedēkli no- plašsaziņas līdzekḷos, Daiki Horiguči (Daiki Horiguchi 2011, 104) konstatē, ka priedēklis no- spēj pievienoties citvalodu izcelsmes pamatverbiem ar lıoti dažādām leksiskajām nozīmēm - objekta izveidošanas noorganizēt, stāvokḷa maiņas notonèt, domu norezonèt, runas nokomandèt, aktivitātes virzības nofilmēt un citu nozīmju verbiem. „Mantotie priedēkḷverbi ir vārddarināšanas procesā jau „sen gatavi”, turpretī aizgūtie vārdi, tikko ienākuši valodā, parasti ir bez prefiksa. To pievieno runātājs konkrētā saziṇas situācijā, lai apmierinātu savu valodisko vajadzību." (Horiguči 2013, 47) D. Horiguči $(2014,111)$ īpaši uzsver valodas lietotāja lomu internacionālu verbu darināšanā: „Internacionālu verbu prefiksācijā vērojama lietotāja lielāka iesaistīšanās vārddarināšanā. (..) Meklējot, kā kādu parādību nosaukt kompaktāk, valodas lietotājs veido jaunus vārdus uz analogijias pamata."

\section{Prefiksālais elements re-}

Ir 48 svešcilmes verbi, kurus ievada re-. Latīn,u valodā priedēklim re-vai redir nozīme 'atpakal, atkal, no jauna' (Allen 1903, 162; Strads 2014, 165). Vairums verbu aizgūti jau atvasinātā veidā, piem., reversēt, bet ir arī tādi, kuriem svešcilmes priedēklis re- pievienots vārddarināšanas cel̦ā, piem., reeksportēt. L̄̄̄dz̄̄gi kā pašcilmes priedēkḷi, arī svešcilmes prefiksālie elementi var piešķirt verbiem dažādas nozīmes. Pēc nozīmes verbus, kurus ievada re-, var iedalīt vairākās grupās: 
1) Visvairāk verbu izsaka atkārtotu darbību. Dal̦ai verbu ir pašcilmes sinonīmi, kurus ievada priedēklis pār-, piem., refinansēt un pārfinansēt, reǵgenerēt un pārǵenerēt.

(10) Faktiski tā nauda, ko sociālais budžets ir uzkrājis, šobrīd tiek refinansēta un atdota pensionāriem. (SAEIMA)

(11) Arī daudzās citās valstīs sāk ar nelielu deficìtu, bet viņi pārfinansēe no privatizācijas ieņēmumiem. (SAEIMA)

2) Ir verbi, kas izsaka kādas īpašības atcelšanu, atgriešanos iepriekšējā stāvoklī. Pašcilmes sinonīmu ievada priedēklis at-, piem., reabilitēt un attaisnot, rehabilitēt un atveselsot, reanimèt un atdzìvināt, restaurēt un atjaunot.

(12) Cits jautājums gan ir tāds, ka acīmredzot mums varbūt būs jāatrod vēl kādas summas, lai varētu izstrādāt šos projektus, kas tiešām var rehabilitēt šos uznēmumus. (SAEIMA)

(13) Un reizē tā atveselos gan pārstrādes uznēmumus, gan nodrošinās banku, jo tā nauda, Oša kungs, tik un tā ienāks bankā. (SAEIMA)

3) Ir verbi, kas izsaka stāvokḷa maiṇu. Sinonīmam parasti ir priedēklis pār-, piem., reformèt un pārveidot.

(14) Reformējot tautsaimniecību, tiesisko sistēmu, valsts pārvaldi, cenšamies saglabāt sociālo stabilitāti. (SAEIMA)

(15) Šeit arī ļoti svarīgi, lai mēs turpinātu pārskatīt un pārveidot vecāku pabalstu un bērna kopšanas pabalstu sistēmu tā, lai tā bütu caurskatāmāka, saprotamāka. (SAEIMA)

Eksistē vēl citas, šaurākas nozīmes, kuras piemīt verbiem, kurus ievada re-. No īpašības vārdiem darinātiem prefiksāliem verbiem, kuri izsaka īpašības kvalitatīvu vai kvantitatīvu samazināšanos, tiek lietoti arī svešcilmes ekvivalenti: reducèt un samazināt, regresèt un pasliktināties. Specifiskas nozīmes ir vēl šādiem svešcilmes un pašcilmes sinonīmu pāriem: rekomendèt un ieteikt, reprezentēt un pārstāvēt, rezidèt un uzturēties, rezonèt un atbalsot, rezumèt un apkopot, revanšéties un atspēlēties. Daļai verbu pašcilmes sinonīmi netiek lietoti, piem., reeksportèt, revakcinèt, reevakuēt, retušêt. Nevar saskatìt viennozīmīgu atbilsmi starp svešcilmes priedēkli re- un kādu pašcilmes priedēkli. Latviešu valodā verbi netiek lietoti visās latīṇu priedēkḷa re- nozīmēs. Piem., nozīme 'atpakal̦' piemīt verbam reflektēt, nozīme 'no jauna' piemīt verbam reduplicēt, bet nozīmes 'rūpīgi' un 'pretim' nav konstatētas.

\section{Prefiksālaie elementi in-, im-}

Latviešu valodā ir aptuveni 52 svešcilmes verbi, kurus ievada in-, im-. 16 verbiem konstatēti arī pašcilmes sinonīmi. Latīṇu valodā priedēklim in- ir nozīme 'iekšā, uz, virsū, pret' (Allen 1903, 161; Strads 2014, 163). Šis priedēklis izsaka arī noliegumu 'ne' (Skujiṇa 1999, 54). Latịnu valodā priedēkḷa līdzskanis var asimilēties un pielīdzināties pamatvārda sākuma līdzskanim, tādēḷ vārds var sākties ar skaņām im-, ir- un il-. Latviešu valodā ir verbi, ko ievada latīṇu cilmes 
il- - ilustrēt un iluminēt, verbu imigrēt ievada latīṇu cilmes im-, nav konstatēti verbi, kurus ievadītu latīnu cilmes ir-

Visspilgtāk izteikta ir nozīme 'iekšā'. Tā piemīt sinonīmu pāriem importēt un ievest, injicēt un iešlıircināt, impregnèt un piesātināt, inkorporēt un iekļaut, investèt un ieguldìt un vēl citiem verbiem.

(16) Šo naudu, kuru mēs plānojam savākt ar šs̄ likuma palīdzību, mēs netaisāmies krāt vai investēt kaut kur. (SAEIMA)

(17) Ja mēs ieguldām šos 2,8 miljonus, tad tam vajadzēs vairāk nekā simts gadu. (SAEIMA)

Vēl citas nozīmes piemīt sinonīmu pāriem inkriminèt un apsūdzèt, iniciēt un aizsākt, inspicèt un pārbaudīt, instalèt un uzstādìt.

Ir sastopams arī negatīvas nozīmes piemērs. Verbs imobilizēt izsaka nozīmi 'padarīt nekustīgu'. Svešcilmes vārdam intrig̀gèt, kurš aizgūts jau atvasinātā veidā, tiek lietoti vairāki pašcilmes priedēkḷi - ie- un $s a$-, kuri izsaka aizsāktu darbību un līdz galam veiktu darbību.

(18) Varbūt šie secinājumi varētu ieintrigèt arī nopietnu avīžu galvenos redaktorus .. (SAEIMA)

(19) .. mani mazliet saintrigèja mana kolèga un Tautas partijas biedra runa .. (SAEIMA)

\section{Prefiksālais elements dis-}

Latviešu valodā ir aptuveni 12 svešcilmes verbi, kurus ievada dis-. Visi verbi aizgūti jau atvasinātā veidā. Latīṇu valodā priedēklim dis- (varianti dī-, dif-, dig-, dir-) ir nozīme 'atsevišksi, nošķirti, projām, uz dažādām pusēm, l̦oti' (Allen 1903, 162; Strads 2014, 165), savukārt griek̦u valodā priedēklis dis- „norāda uz traucējumu, bojājumu, apgrūtinājumu” (Skujiṇa 1999, 29). „Svešvārdu vārdnīca” sniedz šādu skaidrojumu: „1) tāds vai tas, kas ir šķirts no .., sadalīts (piem., dispersija, distribūcija); 2) tāds vai tas, kas kaut kas nav vai ir kaut kam pretējs (piem., disharmonija).” (Baldunčiks 1999, 158)

Angḷu valodā dis- visbiežāk izsaka nevēlēšanos veikt darbību, kuru izsaka verba sakne: dislike, disapprove. Retāk dis- izsaka pretstatu: 1) transitīiviem verbiem apvēršot darbību, kuru izsaka verba sakne: discharge, disempower; 2) atbrīvojot no lietas, ko izsaka verba sakne: displace, disqualify.; 3) apzīmējot abstraktas lietas, ko apzīmē sakne, neesamību: disrespect (Hamawand 2011, 71-72).

Sākotnējā dis- nozīme saglabājas arī aizguvumos latviešu valodā. Vairākiem šīs grupas verbiem ir negatīva nozīme, piem., diskriminèt. Tā var būt saistìta ar atbrīvošanu no kaut kā, piem., diskvalificēt, vai kaut kā izjaukšanu, traucēšanu, piem., disharmonēt, disonèt. Verbam dislocēt ir nozīme ,izvietot (bruņotos spēkus, karaspēka daļas, militāras iestādes kādā teritorijā, frontē, bāzē u.tml.)" (sk. „Mūsdienu latviešu valodas vārdnīca”). Tātad dis- simbolizē izkliedi noteiktā apgabalā, kas sasaucas ar latịnu priedēkḷa skaidrojumu 'uz dažādām pusēm'.

(20) Republikas teritorijā ir dislocētas un darbojas trīs kara prokuratūras: Skrundā, Daugavpilī un Rīgā. (SAEIMA) 


\section{Prefiksālais elements de-}

Latviešu valodā ir aptuveni 60 svešcilmes verbi, kurus ievada de-. 12 verbiem konstatēti arī pašcilmes sinonīmi. Latīṇu valodā priedēklim de- ir nozīme ,at-.., lejup.., tāds, kas atdala, pazemina, atcel, likvidē (piem., deaerācija, demobilizācija, degradācija)" (Baldunčiks 1999, 133) vai 'lejup, pilnībā' (Allen 1903, 161). Anglu valodā de- visbiežāk izsaka pretstatu šādās trīs semantiskās situācijās: 1) atcelıtot abstraktu darbību, kuru izsaka sakne: decontrol; 2) atbrīvojoties no objekta, kuru apzīmē nominālā sakne: debug, degas; 3) atņemot abstraktu lietu, ko apzīmē sakne: deform. Retāk de- tiek lietots šādos gadījumos: 1) reducējot lietu, ko nosauc verba sakne: degrade; 2) analizējot abstraktu lietu, ko apzīmē verba sakne: decode, deconstruct, demistify; 3) pametot transporta līdzekli, ko apzīmē sakne: deplain, detrain; 4) atcel̦ot transitīvu darbību, ko nosauc verba sakne: decouple, decommission (Hamawand 2011, 70-71).

Internacionālismu forma un nozīme dažādās valodās ir vienāda vai vismaz l̦oti tuva, jo internacionālisms veic starptautiskās sazināšanās veicinātāja funkciju (Skujiṇa 2002, 143-144). Šo tēzi apstiprina arī piemēru analīze, piem., identiskas nozīmes piemīt angḷu verbam deform un latviešu deformēt. Prefiksālais elements de- latviešu valodā netiek lietots visās angl̦u valodā minētajās nozīmēs. Piem., latviešu valodā nav verbu, kuri apzīmētu saknes izteiktā transportlīdzekḷa pamešanu, tā vietā tiek lietots vārdu savienojums 'izkāpt no autobusa/lidmašīnas/vilciena'.

Latviešu valodā verbu, kurus ievada de-, nozīmju klāsts ir l,oti plašs. Lielākās grupas ir šādas:

1) Verbi, kas apzīmē konkrētu vai abstraktu darbību, kas pretēja saknes nosauktajai darbībai, piem., demobilizèt, dekoncentrēt, dekolonizēt, deaktiv(iz)êt, decentralizèt, defokusēt, demontēt, denacionalizēt (sk. (21) piemēru). Tiek lietoti verbi arī bez šī svešcilmes priedēkḷa (sk. (22) piemēru).

(21).. visi dokumenti liecina, ka īpašums tomēr ir denacionalizējams. (SAEIMA) (22) Šo banku tagad mēs mēǵinām - jeb esam paredzējuši - nacionalizēt. (SAEIMA)

2) Verbi, kas apzīmē darbību, kura tieši vai netieši maina vai bojā objektu vai abstraktu lietu, piem., deformèt, degradèt (sk. (23) piemēru), degenerēties, destabilizèt, depolitizèt, depolarizèt.

(23) Bet nelaime jau ir tā, ka tāds arī ir šo cilvēku nolūks - degradēt Saeimas prestižu. (SAEIMA)

3) Verbi, kas apzīmē darbību, kura atbrīvo objektu no nominālās saknes nosauktā objekta, piem., dehidrēt, dejonizēt, degazēt, dekarbonēt. Š̄is nozīmes verbiem raksturīgi sinonīmi ar pašcilmes priedēkli at- un pašcilmes sakni - atūdeņot, atgāzèt.

4) Verbi, kas apzīmē abstraktas lietas analīzi, piem., dekodēt, dešifrēt. Š̄is nozīmes verbiem raksturīgi sinonīmi ar pašcilmes priedēkli at-, kurš tiek pievienots tam pašam svešcilmes celmam - atkodèt, atšifrēt.

5) Verbi, kas saistīti ar objekta pārvietošanu, piem., deponēt, deportēt. 


\section{Prefiksālais elements pro-}

Latviešu valodā ir aptuveni 15 svešcilmes verbi, kurus ievada pro- (lat. prō(d)-). 10 verbiem konstatēti arī pašcilmes sinonīmi. Latīnu valodā šim priedēklim ir trīs nozīmes: „1) tāds, kas piekrît kaut kam (vai kādam); 2) tāds, kas darbojas kā (vai kāda) interesēs; tāds, kas ir vietnieks vai aizstāj; 3) priekšā..; iepriekš.." (Baldunčiks 1999, 628)

Nozīme 'darboties kāda interesēs' piemīt verbiem protekcionēt, protežèt. Nozīme 'iepriekš kaut ko darīt' piemīt verbiem profilèt, prognozēt, provocèt. Ir verbi, kas izsaka kustību laikā uz priekšu, piem., progresēt, prolongèt, promenèt, producèt, projicèt, projektēt. Vairāku verbu nozīme ir 'paust savu viedokli', piem., protestèt, proklamēt, proponèt. Labumu gūšanu gan negodīgā, gan godīgā veidā izsaka verbi profanèt, profitèt.

Visbiežāk sastopamais pašcilmes priedēklis sinonīmiem ir pa-, piem., paredzēt (sinonīms verbam prognozēt) (sk. (24) un (25)), paildzināt (sinonīms verbam prolongèt), pasludināt (sinonīms verbam proklamēt).

(24) Bet es paredzu, ka nākamajā Saeimā nacionālie spēki tomēr uzvarēs un tauta sapratīs, par ko ir jābalso. (SAEIMA)

(25) Šādi gadījumi ir, un diemžēl var prognozēt, ka šādu gadījumu būs vēl vairāk. (SAEIMA)

Retāk tiek lietoti sinonīmi ar priedēkli iz-, piem., izaicināt vai izraisìt (sinonīmi verbam provocèt) (sk. (26) un (27)), sinonīmi ar priedēkli aiz-, piem., aizsargāt, aizstāvēt (sinonīmi verbiem protežèt, protekcionēt), sinonīmi ar priedēkli ie-, piem., ierosināt (sinonīms verbam proponēt), iebilst (sinonīms verbam protestēt).

(26) Es saprotu, ka jums ir liela vēlme provocēt sociāldemokrātus. (SAEIMA)

(27) Ne jūs spējat runāt tad, kad uzaicina jūs uz debatēm, ne es spēju jūs izaicināt tagad. (SAEIMA)

\section{Prefiksālais elements $a$ -}

Latviešu valodā ir aptuveni 35 svešcilmes verbi, kurus ievada $a$ - vai $a b$ (lat. $\left.\bar{a}-, a b-, a b s-, a s^{-}, a u-\right) .19$ verbiem konstatēti arī pašcilmes sinonīmi. Grieķu valodā priedēklis $a$ - vai an- izsaka noliegumu, latīṇu valodā $a b$ - izsaka virzību prom, savukārt priedēklis ad- izsaka virzību klāt (Skujiņa 1999, 9). Angḷu valodā transitīiviem verbiem $a b$ - izsaka 1) aplami veiktu saknes nosaukto darbību: abuse; 2) kāda atbrīvošanu no darbības, ko izsaka sakne: absolve (Hamawand 2011, 70). Latviešu valodā svešcilmes verbiem, ko ievada $a$ - ir pretējas nozīmes. Ir verbi, kuros $a$ - izsaka nozīmi 'prom', piem., anulēt. Taču vairumam verbu $a$ - izsaka nozìmi 'klāt', piem., akumulèt, anotèt, asimilèt.

Sinonīmiem visbiežāk tiek lietots pašcilmes priedēklis pie-, kurš izsaka nozīmi 'klāt', piem., pielāgot (sinonīms verbam adaptēt) (sk. (28) un (29)), asignèt (sinonīms verbam piešķirt).

(28) Šā likumprojekta mērķis ir uzlabot tiesisko regulējumu elektronisko sakaru nozarē un adaptēt vairākas Eiropas Savienības direkt̄̄vu prasības. (SAEIMA) 
(29).. mēs grozām Civilprocesa kodeksa normas, lai pielāgotu tās Civillikuma normām. (SAEIMA)

\section{Citi svešcilmes prefiksālie elementi}

Latviešu valodā ir aptuveni 40 svešcilmes verbu, kurus ievada ko- (lat. cum-, co-, col-, com-, con-, cor-). 14 verbiem konstatēti arī pašcilmes sinonīmi. Latīṇu valodā priedēklim ir nozīme 'kopā, savstarpēji saistīts, līdz ..' (Baldunčiks 1999, 360). Nozīmju klāsts ir diezgan ierobežots. Verbi ar šo prefiksālo elementu izsaka kopēju darbību, piem., koordinēt, kooperēties vai arī virzību kopā, piem., kompilèt, koncentrēt. Šo verbu sinonīmiem tiek lietoti dažādi pašcilmes priedēkḷi. Visbiežāk sastopami sinonīmi ar priedēkli sa-, piem., sabiezināt (sinonīms verbam kondensēt), sazināties (sinonīms verbam komunicēt), sarakstīties (sinonīms verbam korespondèt). Sinonīmiska nozīme ir arī pašcilmes prefiksoīdam $l \bar{\imath} d z$-. Tas tiek lietots adverba $l \bar{l} d z i$ nozīmē, apzīmējot procesa vai darbības kopīgu norisi. Sinonīmiskas iezīmes ir verbiem lìdzdarboties un kooperēties.

Verbu ar citiem prefiksāliem elementiem skaits ir mazāks. Tie ir aizgūti jau atvasinātā veidā. Latīnu priedēkḷa ad- nozīme 'tuvoties, uz, klāt' (Allen 1903, 161; Strads 2014, 162) ir arī latviešu valodā, piem., vārdam adoptēt. Latīṇu priedēklim ex- ir nozīmes 'laukā no, loti, pilnīgi' (Allen 1903, 161; Strads 2014, 163). Latviešu valodā minami vārdi ekshumēt (sinonīms izrakt no zemes), ekstrahēt (sinonīms izraut), eksplodēt (sinonīms uzsprāgt), eksponèt (sinonīms izlikt apskatei) un citi. Visbiežāk pašcilmes sinonīmiem ir priedēklis iz-. Latīnu priedēkḷa prae- nozīme ir 'priekšā, pa priekšu' (Strads 2014, 164). Tā saglabājas gan angḷu, gan latviešu valodā. Angḷu valodā galvenā nozīme ir secība laikā (Hamawand 2011, 63). Š̀̃ nozīme piemīt transitīviem verbiem. Verbs apzīmē iepriekš veiktu darbību, kuru apzīmē verba sakne: prepay, prejudge. Secību laikā izsaka arī latviešu verbs predisponēt. Retāka nozīme - secība telpā. Secību telpā izsaka latviešu verbs prezidèt.

\section{Secinājumi}

Svešcilmes verbi ir nozīmīga latviešu valodas leksikas daļa, kas bagātina valodu, nodrošinot sinonīmiskas izteiksmes iespējas. Svešcilmes verbus var aizgūt jau atvasinātā veidā, piem., konvertēt. Latīn,u vai grieķu cilmes priedēklis ir pievienots verbam jau donorvalodā. Latviešu valodā tiek lietoti atvasināti svešcilmes verbi ar ietvertu latīņu vai grieķu prefiksālo elementu re-, de-, in-, $k o-, a d-, a b-, a-, e k s-, s u b-$, pre-, pro- un vēl citiem, kuri šajā pētījumā netika aplūkoti. Latīṇu cilmes priedēkḷi re- un de- tiek pievienoti verbiem arī tad, kad tie ienākuši latviešu valodā, piem., refinansēt. Svešcilmes verbiem mēdz pievienot arī pašcilmes priedēkḷus, piem., pārfinansēt. Tāpat kā pašcilmes verbos, arī svešcilmes verbos priedēklis raksturo darbības pabeigtību un vienreizējas/daudzkārtējas darbības pretstatu.

Paralēli lietojamus verbus (sinonīmu pārus) pēc saknes un priedēkḷa cilmes var iedalīt piecās grupās: 1) gan svešcilmes verbam, gan tā pašcilmes sinonīmam ir pašcilmes priedēklis, piem., ieekonomēt un ietaupīt; 2) svešcilmes verbam ir gan svešcilmes, gan pašcilmes priedēklis, pašcilmes sinonīms netiek lietots, piem., 
restartēt un pārstartēt; 3) svešcilmes verbs aizgūts jau atvasinātā veidā, pašcilmes sinonīmam ir pašcilmes priedēklis, piem., reducēt un samazināt; 4) svešcilmes verbam ir svešcilmes priedēklis, bet pašcilmes sinonīmam - pašcilmes priedēklis, piem., deklasificēt un atslepenot; 5) svešcilmes verbs aizgūts jau atvasinātā veidā, pašcilmes sinonīma nav, piem., retvītot.

Svešcilmes verbu un to pašcilmes sinonīmu analīze l̦auj konstatēt dažas sakarības starp svešcilmes un pašcilmes priedēkḷiem. Visas latīṇu priedēkḷu nozīmes verbos, kuri ienākuši latviešu valodā, nav konstatētas. Nav konstatēta viennozīmīga atbilstība starp kādu latīnuu cilmes priedēkli un pašcilmes priedēkli, taču pastāv atbilstība starp noteiktām latīnu cilmes priedēkḷa nozīmēm un pašcilmes priedēkḷa nozīmēm. Atkārtotu darbību izsaka svešcilmes verbi, kurus ievada re- un pašcilmes sinonīmi ar priedēkli pār-, piem., regenerēt un pārgenerēt. Kādas īpašības atcelšanu, atgriešanos iepriekšējā stāvoklī izsaka svešcilmes re- un pašcilmes at-, piem., rehabilitêt un atveseļot. Virzienu 'iekšā' izsaka svešcilmes in- un pašcilmes ie-, piem., inkorporēt un ieklaut. Darbību, kura atbrīvo objektu no nominālās saknes nosauktā objekta, vai arī abstraktas lietas analīzi apzīmē svešcilmes de- un pašcilmes at-, piem., dehidrēt un atūdeņot, dešifrēt un atšifrēt. Nozīmi 'klāt' izsaka svešcilmes $a$ - un pašcilmes pie-, piem., adaptēt un pielāgot. Kopēju darbību izsaka svešcilmes ko- un pašcilmes sa-, piem., komunicēt un sazināties.

Piemēriem izmantots Saeimas sēžu stenogrammu korpuss, kas parāda, ka viena stila tekstos līdzvērtīgi tiek lietoti gan pašcilmes verbi, gan svešcilmes aizguvumi, kuri valodā ir tik labi iekḷāvušies, ka to atvasināšanā tiek izmantoti arī latviešu valodā lietotie vārddarināšanas līdzekḷi - pašcilmes priedēkḷi.

\section{Avoti}

SAEIMA - Saeimas sēžu stenogrammu korpuss. Atrodams darba autores personīgajā arhīvā.

\section{Literatūra}

1. Allen, Joseph H. 1903. Allen and Greenough's New Latin grammar for schools and colleges: founded on comparative grammar. Boston, London: Ginn \& Company. Pieejams: http://www.textkit.com/downloads/2 [Skatīts 19.02.2017.]

2. Hamawand, Zeki. 2011. Morphology in English: word formation in cognitive grammar. London: Continuum.

3. Horiguči, Daiki. 2011. Perfektīvie citvalodu izcelsmes no-verbi plašsaziņas līdzekḷlos. Vārds un tā pētī̌̌anas aspekti. 15(I). Liepāja: LiepU, 100-108.

4. Horiguči, Daiki. 2013. Priedēkḷi kā internacionālismu „nacionalizācijas” līdzekḷi. Valoda: nozìme un forma. 3. Kalnača, Andra, Lokmane, Ilze (red.). Rīga: LU Akadēmiskais apgāds, 45-56.

5. Horiguči, Daiki. 2014. „Vārda darināšanas brīvība” un internacionālo verbu prefiksācija. Valodas prakse: vērojumi un ieteikumi. 9. Rīga: Latviešu valodas ağentūra, 110-122.

6. Kalnača, Andra. 2004. Morfêmika un morfonologiija. Rīga: LU Akadēmiskais apgāds. 
7. Kuzņecova, Tatjana. 2013. Dažas piezīmes par aizguvumu kopām morfolog̣ijas un semantikas aspektā. Vārds un tā pētī̌sanas aspekti. 17(I). Liepāja: LiepU, 112121.

8. Skujiņa, Valentīna. 1999. Latīņu un grieķu cilmes vārddaļu vārdnīca. Rīga: Kamene.

9. Skujiņa, Valentīna. 2002. Latviešu terminoloǵijas izstrādes principi. Rīga: LU Latviešu valodas institūts.

10. Soida, Emīilija. 2009. Vārddarināšana. Rīga: LU Akadēmiskais apgāds.

11. Strads, Māris. 2014. Lingua Latina: latīnu valodas gramatika. Rīga: Jumava.

12. Veisbergs, Andrejs. 2001. Word-Formation in English and Latvian. Contrastive analysis. Rīga: LU Akadēmiskais apgāds.

13. Vulāne, Anna. 2013. Vārddarināšana. Latviešu valodas gramatika. Nītiṇa, Daina, Grigorjevs, Juris (red.). Rīga: LU Latviešu valodas institūts, 190-299.

14. Zuicena, Ieva (red.). Mūsdienu latviešu valodas vārdnīca. Rīga: LU Latviešu valodas institūts. Pieejams: http://tezaurs.lv/mlvv/ [skatīts 27.09.2016.]

\section{Summary}

The loanwords take up the considerable part of the lexicon. In this research the relations between the loan verbs, their native synonyms and prefixes of a foreign and a native origin are explored. Some international verbs are already prefixed before borrowing by the prefixes of Latin or Greek origin, other verbs are prefixed after borrowing. In this research the meaning of the prefixes re-, de-, in-, ko-, ad-, $a b-, a-, e k s-, s u b-$, pre-, pro- as a part of a stem of a borrowed verb is explored. Prefixes re- and de- are sometimes used in loan verb formation also in Latvian. The loan verbs can be affixed also by prefixes of a native origin.

By exploring the loan verbs and their synonyms some connections between the prefixes of a different origin are detected. Not all meanings of the prefixes of a Latin origin are found in the borrowed verbs in Latvian. There is no direct equality between some prefix of a Latin origin and some prefix of a native origin in general, however there is equality in some meanings. The five groups of verbs can be distinguished: 1) both, the borrowed verb, and it's synonym of a native origin have a prefix of a native origin; 2) the borrowed verb has a prefix of a foreign origin and a prefix of a native origin, but does not have a synonym of a native origin; 3 ) the borrowed verb already prefixed before borrowing, the native synonym has a prefix of a native origin; 4) the borrowed verb has a prefix of a foreign origin, the native verb has a prefix of a native origin; 5) the borrowed verb already prefixed before borrowing, the native synonym does not exist.

All examples used in this research are from a single data source - the corpus of the transcriptions of the sessions of the Saeima (the Latvian parliament). It shows that both verbs of a foreign origin, and their synonyms of a native origin, are used on equal terms, which confirms a tight integration of the loan verbs in Latvian. 